\title{
Investigating Iraqi EFL Secondary School Students' Perceptions towards Using Mobile Language Learning Technique
}

\author{
Nisreen Kadhim Khudhair ${ }^{1}$ \\ ${ }^{1}$ Methods of Teaching English, Instructor at Ministry of Education-Iraq \\ Correspondence: Nisreen Kadhim Khudhair, Methods of Teaching English, Instructor at Ministry of Education- \\ Iraq. E-mail: nisreenkadhim2009@gmail.com
}

Received: March 29, 2021; Accepted: May 3, 2021; Published: May 7, 2021

\begin{abstract}
Changes in mobile technologies, developments in information technologies and telecommunication, computers programs and expansion of mobile market, likewise have inspired people to make use of these "anytime" and "anywhere" technologies in second language teaching. Use of mobile devices in language teaching has been the focus of language learning studies since language learning necessitates interaction and autonomy which are the key concepts in mobile assisted language learning for learners.

The research aims at investigating Iraqi EFL secondary school students' perceptions towards using mobile language learning technique.

To achieve the aim of the present research, a sample of 40 secondary school students were chosen randomly from many schools .

To fulfill the aim of the study, the questionnaire of students consists of (17) items. After the analysis of the data, the findings indicated that the vast majority of students had had used their mobile phones to study English. Also, they expressed their welcome towards using this technology to study English in the future.

It is recommended to promote the use of mobile learning devices, and encourage students to use mobile as a means of learning and teaching English language in various stages of education.
\end{abstract}

Keywords: Students' Perceptions, Mobile Language Learning Technique

\section{Introduction}

\subsection{Problem of the Study}

Technology is transforming how human communicate, socialize, play, shop and conduct business. These profound changes place pressure on the traditional models of language learning, like teaching in a formal classroom setting. They also present us with amazing opportunities to re-design the way person teach and learn English.

Mobile language learning is defined as the use of mobile devices including mobile phones and other means of wireless communication for language learning (Richards \& Schmidt, 2010, p. 35).

Mobile language learning technique has become a tool in class that students can use to practice English through translation, vocabulary, and social media apps among others provide communicative skills for adult students. "Learning across multiple context ,through social and content interaction, using personal electronic devices" (Crompton, 2013, p. 4).

Moreover, There are many technologies such as social media apps and podcasting have contributed to developing conversation, speaking and writing skills by allowing learners who study English as a foreign language to interact with those whose first language is English. Adekola et al. (2018, p. 65).

Along with the rapid improvements in technology, mobile devices have become widespread in the last few decades. The affordances of mobile devices their ability to prompt learning which is locally situated but globally linked, initially episodic but ultimately extended. It is a type of teaching and learning process that assisted by the computer software (Pegrum, 2014, p. 35).

Language learners should be able to connect classroom environment to authentic situations knowledge in order to master a meaningful learning of the second language . 
Mobile learning procedure is seen as an enormous and fruitful tool towards the accessibility of educating and elearning for learners through the foremost commonly utilized implies of communication among learners .so, the mobile devices allow for getting of the larger part of learners in all grades from preliminary school to college and have numerous applications (Lal \& Aljundi, 2011, p. 161).

In the classroom as well as on excursions mobile devices promote situated learning as learners receive or seek knowledge from online sources, peer and mentors to inform their interactions with their contexts, and can improve communicative competence with the assistance of mobile devices like cell phones and mp3 players (Pegrum, 2014, p. 61).

Gong(2005, p. 49) states that through mobile language learning environment we can learn anywhere even if we are moving. Moreover, we can access the learning system that we want, whenever we request and where we need. This characteristic gives us a chance of self-regulated learning.

Mobile language learning technique has become indispensable means for everyday life since of their portability, the assemblage of technologies , and the diminishing cost for the devices and services (McCarty et al., 2016, p. 24). Assuming learners are constantly connected with their mobile devices, it is possible to send content, activities, or simply reminders to learners regularly. These messages have the potential to shift attention to the learning task. However, they can also interrupt other more or equally valid activities, particularly in the workplace.

Mobile learning technique includes devices such as MP3, you tube, smart phones, MP4 players, translation and e-book readers through to laptop and tablet computers. As a whole, it is possible to say that mobile learning is creating an interactive learning context with multiple chances for using different kinds of applications which are available in the apparatus (mobile).

It is crucial, however, for students, teachers, policymakers, and employers to be keenly aware of the physical, pedagogical, and psycho-social issues involved in successful implementation of Mobile language learning technique.

\subsection{Importance of the Problem}

The present research aims to clarify the value of using mobile learning technique to improve teaching and learning processes of English in the secondary schools.

The present study is expected to be value for teachers of English to devise the alternative methods and techniques that will help them to assess their students' overtime. Iraqi EFL students for using mobile technique in learning English language.

\subsection{Describe Relevant Scholarship}

Many scholars define mobile learning as a process of gaining knowledge through conversations across multiple contexts among people and personal using interactive technologies with a focus on contexts . The technology implies in this process includes any kind of handheld mobile devices such as cell phones, personal digital assistants (PDAs), smartphones, pads, pods, etc. Others define it as the use of mobile technologies in language learning, especially in situations where device portability offers specific advantages (Kukulska-Hulme, 2013, p. 61).

Mobile learning technique is regarded as a form of distance learning; which refers to the appropriateness of the teaching and learning of languages, since it includes audio and mobile features which improve English language acquisition skills; which is the primary language in the technology system and wireless communications. Learners can get more information on the web, online dictionaries, answered quizzes taking tests, shared ideas and works (Wishart, 2017, p. 65).

\subsection{The Hypothesis}

The use of mobile language learning technique has no impact on the Iraqi secondary school EFL students in learning English language. The study will be limited to: Iraqi EFL secondary school students. Secondary schools which occur in the average of Baghdad Al-Karkh $2^{\text {nd. }}$ The academic year 2018-2019.

\section{Method}

\subsection{Method Subsections}

To achieve the aim of the present study, the following procedures will be adopted by the researchers to collect data:

1. Choosing a number of Iraqi EFL secondary school students (at random) to represent the study sample 
2. Preparing scaled questionnaire under the supervision of a number of specialists who examine its validity and make any comments, suggestions and modifications if necessary.

3. Interpreting the results in the light of the hypothesis by using the proper statistical means that suit the study.

\subsection{Participants Characteristics}

Participants for this study were Iraqi English foreign language secondary school students. Secondary schools which occur in the average of Baghdad Al-Karkh $2^{\text {nd }}$.

\subsection{Sampling procedures}

The population of this study consists the Iraqi EFL secondary school students.

\subsubsection{Sample Size}

Forty secondary school students were chosen randomly to represent the main study sample and other twenty students represent the pilot administration.

\subsubsection{Measures and Instrument}

In order to gain the aims of this research, a questionnaire has been structured for students to be the instrument used as shown in table below.

Table 1. Items of students' questionnaire

\begin{tabular}{|c|c|c|c|c|}
\hline No. & Item & Agree & $\begin{array}{l}\text { Partially } \\
\text { Agree }\end{array}$ & $\begin{array}{l}\text { Dis- } \\
\text { agree }\end{array}$ \\
\hline 1 & Mobile Language learning contributes to increase in My achievement. & & & \\
\hline 2 & Mobile Language learning helps me to improve my language proficiency. & & & \\
\hline 3 & $\begin{array}{l}\text { Mobile Language learning can introduce me to how language is used in the } \\
\text { real world. }\end{array}$ & & & \\
\hline 4 & It can improve my reading comprehension ability more than textbooks do. & & & \\
\hline 5 & Composing mobile language learning are better as written activities. & & & \\
\hline 6 & $\begin{array}{l}\text { It increases my knowledge of vocabulary items which I need in real } \\
\text { situations. }\end{array}$ & & & \\
\hline 7 & Allowing for my' inspiration and reflection. & & & \\
\hline 8 & $\begin{array}{l}\text { It increase my familiarity with the use of grammar rules in their original } \\
\text { context. }\end{array}$ & & & \\
\hline 9 & $\begin{array}{l}\text { I enjoyed the use of mobile technique in my classes because it promoted } \\
\text { creativity and collaboration with my classmates. }\end{array}$ & & & \\
\hline 10 & $\begin{array}{l}\text { Using mobile technique provided more opportunities to learn and study in } \\
\text { places I couldn't normally learn and study in. }\end{array}$ & & & \\
\hline 11 & $\begin{array}{l}\text { It was easier to complete some class work and assignments using my } \\
\text { mobile }\end{array}$ & & & \\
\hline 12 & $\begin{array}{l}\text { The limited Internet access make difficult the use mobile technique as } \\
\text { learning tools inside the classroom. }\end{array}$ & & & \\
\hline 13 & It has negative effect on practice of effective teaching strategies. & & & \\
\hline 14 & $\begin{array}{l}\text { I feel motivated to use my mobile technique outside the classroom to } \\
\text { research topics of personal interest related to English language learning. }\end{array}$ & & & \\
\hline 15 & $\begin{array}{l}\text { To me it is good and very useful, because nowadays we have and interact } \\
\text { with a lot of technology around us. We need to give it a proper use in all } \\
\text { aspects and places. }\end{array}$ & & & \\
\hline 16 & $\begin{array}{l}\text { I think it would be quite useful because we can learn more and in different } \\
\text { ways as a group }\end{array}$ & & & \\
\hline 17 & $\begin{array}{l}\text { I completely agree with this because in that way we can learn more through } \\
\text { cell phones. We can do some feedback of what we have already studied in } \\
\text { class. }\end{array}$ & & & \\
\hline
\end{tabular}




\subsubsection{Research Design}

The quantitative research design uses for this study. In order to gain information about the Iraqi EFL secondary school students' perceptions towards using mobile language learning technique in their classes. A questionnaire have been constructed .

\subsubsection{Experimental Manipulations}

In order to achieve the face validity of the questionnaire, the first copy has been exposed to the experts in the fields of linguistics and methodology of teaching English as a Foreign language.

The experts have been asked to value whether the content of the questionnaire are appropriate or not. Depending on the experts' judgment, some items have been updated and others have been deleted. However, the items 12 \& 14 from the students' questionnaire content have been changed .The final version of the students' questionnaire consists of 17 items. The rating scale includes the following options: Agree, partially agree, and disagree.

In order to assures the construct validity, the questionnaire has been applied to the pilot sample. Then, the construct validity has been fillfuled by using "Pearson Correlation Formula".

$$
r=\frac{N \sum x y-\sum x \sum y}{\sqrt{\left[N \sum x^{2}-\left(\sum x\right)^{2}\right]\left[N \sum y^{2}-\left(\sum y\right)^{2}\right]}}
$$

A survey is solid when it yields the same outcomes about over a given time. In any case, the survey has been perused served to the same pilot test after two weeks. By utilizing Pearson Relationship Coefficient equation the result yields 0.81, while, by utilizing Alpha Cronbach Equation the result yields 0.82 .

$$
\mathrm{a}=\frac{\mathrm{n}}{\mathrm{n}-1}\left[1-\frac{\sum \mathrm{s}_{1}^{2}}{\mathrm{~s}_{\mathrm{x}}^{2}}\right]
$$

After guaranteeing the validity of the survey, a pilot adaptation is managed to a test of twenty students have been chosen randomly from distinctive secondary school for the pilot organization. With respect to the time apportioned for the pilot test is prohibited from the entire sample of the study.

Results of the pilot administration can be a good indicator for making any necessary modifications in the final version of the questionnaire and to determine the effectiveness of the items in the light of the subjects' responses.

The Last frame of the survey was conveyed to the members at the mid of February 2019. The instructors were inquired to grant their views on the items concurring to scale.

The period of distributing and accepting the versions of the survey kept going from the mid of February to the mid of March 2019. 3

\section{Results}

In order to examine the hypothesis of the study which tackles "investigating Iraqi EFL secondary school students' perceptions toward using mobile language learning technique". The answers of the subjects were examined by utilizing the cruel and the speculative cruel equation.

The mean score of the subjects was (45.22) compared with the hypothetical mean (34).

Results mean that the mean is higher than the theoretical mean. This demonstrates that utilizing of mobile language learning technique has affect on the Iraqi secondary school students in learning English language .

Table 3. Weighted Mean of the Questionnaire items

\begin{tabular}{lllll}
\hline Item (NO.) & I Agree & I partially agree & I disagree & Weighted Mean \\
\hline $\mathbf{1}$ & 35 & 5 & 0 & $87.5 \%$ \\
$\mathbf{2}$ & 40 & 0 & 0 & $100 \%$ \\
$\mathbf{3}$ & 38 & 2 & 0 & $95 \%$ \\
$\mathbf{4}$ & 31 & 7 & 2 & $77.5 \%$ \\
$\mathbf{5}$ & 34 & 6 & 0 & $85 \%$ \\
$\mathbf{6}$ & 28 & 10 & 2 & $70 \%$ \\
\hline
\end{tabular}




\begin{tabular}{lllll}
\hline $\mathbf{7}$ & 40 & 0 & 0 & $100 \%$ \\
$\mathbf{8}$ & 35 & 3 & 2 & $87.5 \%$ \\
$\mathbf{9}$ & 24 & 11 & 5 & $60 \%$ \\
$\mathbf{1 0}$ & 17 & 11 & 12 & $42.5 \%$ \\
$\mathbf{1 1}$ & 9 & 13 & 18 & $22.5 \%$ \\
$\mathbf{1 2}$ & 28 & 11 & 1 & $70 \%$ \\
$\mathbf{1 3}$ & 25 & 13 & 2 & $62.5 \%$ \\
$\mathbf{1 4}$ & 18 & 7 & 15 & $45 \%$ \\
$\mathbf{1 5}$ & 36 & 3 & 1 & $90 \%$ \\
$\mathbf{1 6}$ & 37 & 3 & 0 & $92.5 \%$ \\
$\mathbf{1 7}$ & 34 & 6 & 0 & $85 \%$ \\
\hline
\end{tabular}

\section{Discussion}

Mobile-assisted language learning (MALL) can augment second language teaching and learning by taking it into the real world.

Authentic communicative situations in conjunction with the cultural artifacts and metalinguistic clues offered by the context can promote active learning.

This research was constructed to explore students' perception to mobile phone using for English language learning. The findings indicated that the vast majority of students had had used their mobile phones to study English. Also, they expressed their welcome towards using this technology to study English in the future. Although this is just an exploratory study on students' perceptions, it provides teachers and educators with useful information regarding a novel teaching and learning method.

Besides, there's a solid endorsement of the conceivable employments of mobile learning to improve instructing and learning of the English dialect among understudies at the secondary stage . So, using of mobile language learning technique has impact on the Iraqi secondary school students in learning English language.

Based on the outcomes of the study, many recommendation are :

1- Promoting the utilize of mobile learning devices, and encourage learners to form utilize of it to support the teaching and learning of English language in different stages of instruction.

2- Take advantage of the numerous parts of mobile learning devices of different sorts to improve instructing and learning of English language in different stages of instruction.

3- The necessity of holding scientific seminar for supervisors and teachers of English language ; To find out their opinions and attitudes towards the usefulness and feasibility of hiring such advanced technologies to support teaching and learning of the English language.

4- The need of holding scientific seminar for administrators and instructors of English language; To discover out their conclusions and attitudes towards the value and possibility of contracting such progressed innovations to develop English language teaching and learning processes.

5- Set up training courses for supervisors and teachers of English language which tackled the communications and information technology and its role in supporting the teaching and learning of the English language.

In the light of the results of the study and its recommendations researcher suggested conducting future studies as follows:

1 - investigate the perceptions and experiences of secondary stage students towards the using of mobile devices and technique to promote learning the English language.

2- Study the importance of utilizing mobile technique for supporting the teaching and learning of the English language at the university stage.

3- improve the effectiveness of the utilizing mobile learning technique in the achievement of the English language and develop thinking skills in the various stages of education.

\section{References}

Adekola, B. O., FataiLawal, O., \& Ibrahim, O. A. (2018). Mother Tongue and Learning Environment as Students' Predictors of Academic Achievement in Reading Comprehension. International Linguistics Research, 1(1). 
62-66. https://doi.org/10.30560/ilr.v1n1p62

Crompton, H. (2013). A historical overview of mobile learning: Toward learner-centered education. In: Berge, ZL, Muilenburg, L. Y. (eds.). Handbook of Mobile Learning. Florence, Kentucky: Routledge, pp. 3-14.

Gong, S. (2005). A study of teaching-learning model in m-Learning environment. Gyeogin National University of education, thesis, unpublished.

Kukulska-Hulme, A. (2013). Mobile-assisted language learning. In C. Chapelle (Ed.), The encyclopedia of applied linguistics (pp. 3701-3709). New York: Wiley. https://doi.org/10.1002/9781405198431.wbeal0768

Lal, Z., \& Aljundi (2011). Modern technology in the education of mentally superior, the world of books, Cairo.

McCarty, S., Obari, H., \& Sato, T. (2016). Implementing Mobile Language Learning Technologies in Japan. Springer. https://doi.org/10.1007/978-981-10-2451-1

Ogata, H., \& Yano, Y. (2005). Knowledge awareness for computer-assisted language learning using handhelds. International Journal of Learning Technology, 5(1), 435-449. https://doi.org/10.1504/IJCEELL.2004.005731

Pegrum, M. (2014). Mobile Learning: Languages, Literacies and Cultures New Language Learning and Teaching Environments. Springer.

Richards, J. C., \& Schmidt, R. (2010). Longman dictionary of language teaching and applied linguistics. $4^{\text {th }}$ Edition. Great Britain: Pearson Longman.

Wishart, J. (2017). Mobile Learning in Schools: Key Issues, Opportunities and Ideas for Practice. Routledge. https://doi.org/10.4324/9781315536774

\section{Copyrights}

Copyright for this article is retained by the author(s), with first publication rights granted to the journal.

This is an open-access article distributed under the terms and conditions of the Creative Commons Attribution license (http://creativecommons.org/licenses/by/4.0/). 